\title{
The Effect of Large Classes on English Teaching and Learning in Saudi Secondary Schools
}

\author{
Dalal A. Bahanshal ${ }^{1}$ \\ ${ }^{1}$ English Language Institute, King Abdulaziz University, Saudi Arabia \\ Correspondence: Dalal A. Bahanshal, English Language Institute, King Abdulaziz University, P.O. Box 80203, \\ Jeddah, 21589, Saudi Arabia. Tel: 96-650-568-4068. E-mail: d.bahanshal@gmail.com
}

Received: August 12, 2013 Accepted: September 10, 2013 Online Published: October 10, 2013

doi:10.5539/elt.v6n11p49 URL: http://dx.doi.org/10.5539/elt.v6n11p49

\begin{abstract}
The effect of class size on teaching and learning English as a foreign language (EFL) has been through a contentious debate among researchers for a long time. Before the 1950's the concern about the effect of class size and the learning outcomes of students in such classes waned for some time. Yet, researchers have reconsidered the case once again and up to now it is a field of investigation. Therefore, through reviewing the existing literature on this area and examples culled from the teachers' experience, the aim of the present study are twofold: (1) to ascertain the impact of large classes on the teaching and learning outcomes, and (2) to suggest appropriate strategies Saudi secondary teachers can utilize in their large classes to facilitate English teaching and learning. To reach the aim of this study, six Saudi English teachers from two public schools were interviewed to express their perceptions about teaching in large classes. Research results present that all participants find it daunting to teach large classes. Teachers also comment that despite their efforts to elevate the level of language learning in such context, the outcome of their students is considered to be unsatisfactory. They believe that this can be contributed to the fact that there are big numbers of students in one class and wish for the number to be reduced. The study findings shed the light on some useful and effective methods to be applied in large classes which may facilitate the language teaching and learning.
\end{abstract}

Keywords: EFL, large classes, learning outcomes, secondary schools, Saudi Arabia

\section{Introduction}

It seems that English teachers have no doubt that large size of classes is a prime impediment for the efficient English teaching and learning. With more students enrolling in schools, large classes in a country like Saudi Arabia and other developing countries like Egypt, India and Pakistan tend to be obligatory rather than exceptional. Therefore, the problem seems to expand widely. As a matter of fact, large classes are not in and of themselves an issue to look forward to with dread. Admittedly, they require a great intention and careful preparation from teachers before the teaching process takes place. Heppner (2007) views large classes as a small business which should be set up and handled carefully. Generally speaking, experienced English teachers in general and teachers beginning teaching in particular find it onerous to manage a class with a big number of students with various levels and different personalities. Therefore, it is helpful for teachers to divert a lot of class responsibility to students and back up a little and that will give students space to teach each other.

No one is absolutely certain whether small classes are inherently better than the large once in regard to the roles both classes play and their effectiveness on the process of English teaching and learning. Therefore, finding a definition to an idealistic class size which could be applicable in almost all teaching and learning environment tends to be difficult. Interestingly enough, teachers in general and English teachers in particular always favor small classes and believe that students in small classes learn better than their counterparts in large classes as more practice and activities are employed. In fact, their beliefs are not supported by lots of research in this field.

To throw light on this phenomenon, an empirical study was conducted where six Saudi secondary English teachers were interviewed. The general purpose of investigating teachers' experience in teaching large classes was to realize their perceptions towards teaching large classes and the strategies to cope with the existing adverse situations in the classroom. Such understanding is expected to be beneficial in possible improvement of some fruitful and appropriate methods to yield the maximum learning output. However, review on the related literature provided deep insights about the effect of large classes and practical methods English teachers could utilize in 
such contexts. It is anticipated that large English classes do not offer ideal setting where effective teaching and learning could take place. For example, student-centered teaching/learning is almost impossible in large classes.

Nevertheless, a strong willingness to investigate the effect of large classes on English teaching according to teachers' perceptions made the researcher undertake this study where the main theme of this study is to list the problems Saudi secondary teachers/students encounter when learning English in large classes. Therefore, it is the researcher intention to draw on a selection of studies from different research to, firstly, examine the study main goal which is the influence of class size on English teaching and learning, secondly, provide personal examples culled from actual experience, thirdly, recognize the issues of concern to English teachers facing these large classes and finally, furnish some guidance to facilitate the teaching and learning process.

\subsection{Significance of the Study}

Considering teaching English in large classes as a great problem and a real world issue which is worrying Saudi English teachers of all levels in general and secondary teachers in particular, this study aims to investigate the effect of large English classes on the teaching and learning process and suggest some useful strategies to cope with this dilemma as to prompt the language level. To do this, six Saudi secondary English teachers were interviewed to express their point of views towards this phenomenon and to discuss the strategies they have adopted to promote effective teaching and learning in their overcrowded classes. It is the researcher's belief that the findings of the study will help all stakeholders to have a clearness view of the case which may raise the awareness of the problem and add to the body of knowledge about teaching and learning in large classes.

\subsection{Problems Perceived Due to Large Classes}

There are considerable studies concerning the influence of class size on students' improvement but a shortage of consensus on the definition of large and small classes. Thus, this section and the one that follows intend to probe into the causes to plateau of English learning and teaching in large classes. It is the language teachers who hold a negative view against large classes as they believe having many students in one class can cause some problems that affect them and their students. Some commonly comments heard by teachers are: there is no communication, the class is out of control, lack of individual attention and difficult to set effective group activities. Other teachers always emphasize that it is impossible to concentrate on all students and therefore not enough reinforcement will be made to encourage all to participate in different activities. Participants in Al- Jarf's (2006) study commented that "due to the size of the class they do not have enough time to pay attention to each and give every student a chance to speak and participate" (p. 24). In words, such context makes some students, especially the shy or weak, to be neglected and left behind. Kennedy \& Kennedy (1996) shared similar view as they believed it is difficult to overcome all of what occur in class when the number of students exceeds a certain limit.

On the contrary, teachers in small classes are able to pay great attention to their students and the benefit from the presented activities is considered to be high. From that we can say that it is abundantly evident that English teachers encounter great challenges when teaching large classes as they encounter difficulties in knowing all students in the class, having time for all individuals or presenting effective activities and therefore many students, especially the weak ones, tend to lose concentration. Another problem which is borne out in the words of the teachers and hinders the learning process in large classes is identifying and controlling students who tend to distract their classmates from concentrating on the lesson. Lazear (2003) assumed that if a student misbehaves and begins disturbing the class, the teacher has to attend the disturbance and control the noise. Such action from one student or more in a large class will block the learning of that moment and demolish the capability of others to learn. Pedder confirms:

In larger classes, more time is needed for non-academic activities related to administrative and organizational procedures and to the management and control of discipline. Reductions in the quantity of learning opportunities constrain teachers from achieving the necessary pace, depth and breadth of curriculum coverage as class size increases (2006: 224).

Noise level of some students is also considered to be a problematic issue as it will produce disturbance and prevent their classmates from learning. AL-Jarf (2006) recorded that "large class sizes inhibit small group activities and individualized instruction, because of the noise level and lack of space in the classroom" (p. 24). Admittedly, some researchers have found that classroom noise is a result of students' boredom, vague instructions to activities presented in class and teachers' low voice (Harmer, 2000; Lacastro, 2001 and Zhang, 2008).

\section{Literature Review}

Although, there is vast literature on issues regarding teaching and learning English in large classes yet the issue 
still invites many different areas which ought to be explored. This study concentrates on the challenges teachers and students encounter daily in large classes. Through reading the literature, the following studies have been found to quiet closely related to the present study.

Many researchers believe that large classes offer few opportunities to teachers to employ quality teaching and learning environment for learners (Blatchford et al., 2002; Hattie, 2005; Pedder, 2006). Zhang (2002) examined the effect of large classes among college students and proposed that problems are one of three or all. First, discipline problems. Second, students' and teachers' weary. Third, efficient learning. Similar finding was also allocated by Yu (2004) who conducted a study on college students as well studying in large classes. The study showed that individuals' variant is neglected and anxiety is a class predominant. She also pointed that limited practice for the target language due to the large number of students hindered students from improving their level of oral English. Such a conclusion also appeared in a study conducted by Harmer (2000) confirming that large classes bring difficulties to the teaching and learning process in general and to teachers and students in particular as with the big number, teachers find it difficult to organize effective and creative activities, pay attention or contact with all individuals especially those who tend to hide by sitting at the back. Another interesting conclusion found in Harmer's study is that large classes are troubling for experienced teachers but extremely daunting for the new teachers and that emphasize the need of good training and sufficient technical strategies to be employed in large English classes.

The literature review also reveals that the number of studies conducted in the developing countries about class size and large classes are not enough compared with those addressing the issues in the developed world. Therefore, more studies are needed to tackle this field in countries like Saudi Arabia, Oman, Egypt and Jordan. Kumaravadevelu (2006) believed that there is a need for a pedagogical method to investigate the features of large classes in the developing countries and that will provide teachers of those contexts with helpful strategies suitable for their students. Locastro (1989) conducted a study in three urban locations in Japan, Tokyo, Nagoya and Kyoto to investigate the attitudes and expectations of English teachers teaching large classes where the Ministry of Education has no policy on class size. The participants were university teachers as well as teachers and students from different secondary public schools. Classes in schools ranged from $40-50$ students while in university they ranged from $20-100$ students. The researcher was able to collect 96 responses from teachers and lecturers and 94 from students. 33 out of 47 teachers and lecturers were familiar to teaching large classes where they had 41 to 60 students per class. They believed that the average class size is 38 as reaching 39 and above tends to create a serious problem for them and their students. Among the 94 students, 35 had experienced being in classes of 40 to 49 students and only 12 had great experience to be in classes with 200 to 209 classmates and only 8 students studied in classes which had 300 to 309 students.

The study showed that 51 students from those who experienced large classes prefer to be in classes not fewer than 11 and not more than 20. Interestingly enough, 4 students rated a class of 41 students to 51 as ideal. Some students considered a class of 21 students and up to 30 too large while others thought a class of 10 students or fewer is too small. Therefore, Locastro suggested that for effective language teaching to take place in large classes, appropriate methodologies and practices should be applied. The findings of this study were also allocated in different studies carried by other researchers on primary and secondary school students $\mathrm{Su}, 2005$; Tan, 2009; Zhang, 2010). Other studies have also found that students perform better in large classes than in small ones as Pong and Pallas (2001) hypothesized that this could be because teachers with more experience are assigned large classes as they are able to control them but new teachers or less experienced are given small classes which have small numbers of weak students.

\subsection{The Concept of Large Classes}

The effectiveness of class size on students' achievement and motivation, and its synchronous relation to teaching process and teachers' workload, attitudes and motivation, is probably the most written about, however least explored topic in the educational field. Yet, there is no consensus definition in literature to what constitutes a large class as material developers, teachers and students in different parts of world have various perceptions of what frames large, small or ideal classes. Their ideations, therefore, are affected by the educational philosophies, theories and experience of all parties involved in the teaching and learning process. According to Hayes (1997) there is no numerical determination of what shape a large class as teachers' perceptions of large classes differs from one context to another. Hess (2001) assumed that a class is considered large if it has 30 students or more. As regard to the Saudi context, a class of 45 students is considered to be large while in some Far East countries such as Japan, China, Pakistan and India a class of 80 students and more is deemed to be large. 
Ur (1996) believed that regardless to the number of students in a class, it is teachers' perceptions towards the class size in a certain context with particular tools and facilities that are provided that make classes either small or large. Hence, we can say that large classes are those with a specific number of students that teachers cannot handle and resources are not enough to facilitate the teaching and learning process and that pose insurmountable problems for both teachers and students. Mulryan-Kyne (2010) also shares that view and points to a large class as "a class that is too large for effective teaching to occur" (p. 176). Brown (2001), on the other hand, believed that an ideal class should not exceed 12 students. In another word, a class should be big enough to offer variation and allow interaction and small enough to provide students with opportunities for participating and receiving individual attention.

\subsection{Small or Large Classes: Which Are Better?}

As mentioned at the outset of this paper, there are some scholars who favor small classes as they believe that small classes provide ample opportunities for teachers and their students to accomplish the highest level of language achievement. One of these is Miller-Whitehead (2003) who suggested that small classes assist raising teachers' spirit and decrease most of the discipline issues. She elaborates by stating that small classes allow teachers to identify problems quickly and then apply immediate remedial solution and that will eliminate or at least minimize any future disruption. On the other hand, Finn et al. (2003) revealed that class size has great affects on students' social and academic involvement in the class and on the teacher personality as well. That is to say that students in small classes, on contrary to their peers in large ones, are always under pressure to participate in class activities as "they are on the frying line, by being more visible to the teacher and may be called upon at any time to answer questions or to participate in a class activity" (p. 346). On a similar view, Resnick (2003) claimed that smaller classes elevate students' achievement as teachers in such context pay greater attention to each and every student leaving students with no time to either be destructive or distracted by any means. Consequently, students in small classes encounter continuous pressure to engage in various activities and become active class members and that will make the attention to learning goes up and off-task actions as well as any disruptive behaviors go down. On a similar view, Normore and Ilon (2006) conclude that classes of a small size positively influence the teaching process as they encourage students and teacher engagement, allow students to be more cognitively engaged, offer ample time for teachers to cover the whole materials and provide safe school environment with fewer misbehaved students.

Finn et al. (2003) conducted a study to examine how class size affects the social behavior of students and sought to focus on antisocial attitudes such as disruptiveness and misbehavior. From the result of their study, they found that small classes encounter less misbehavior actions than large classes as students in small classes are engaged in more social interactions with their teachers which give them less space to misbehave or fool around. Shamim et al. (2007) reinforced this idea when they revealed that teachers in large classes have problems establishing discipline in their classrooms and dealing with the increasing noise level and that according to Al-Jarf (2006) creates difficulty for students to hear the teacher and concentrate because they are distracted by the actions of their peers. From what have been mentioned in this part, it is to say that large classes have negative influence on teachers and students which reflects on the teaching and learning outcomes.

\subsection{Improving Learning in Large Classes}

With the great number of students enrolling each year in schools and the limited facilities, reducing class size in some teaching context in the developing countries like Saudi Arabia seems to be impossible. Therefore, many scholars have proposed shifting from concentrating on class size to seeking more realistic and effective ways of coping with the situation and exploring the kind of teaching, either in large or small classes, that can produce a difference (Blatchford \& Mortimore, 1994; Blatchford, 2003 and O'Sullivan, 2006). In order to reach this goal, some of the useful advices that have been mentioned in the literature for effective large class teaching will be considered. It is believed that there is no one way to teach large classes. Therefore, a substantial body of research suggests that for effective teaching and learning in large classes, teachers have to consider the followings: the course objectives; the characteristics of their students; and their teaching styles. Some studies have emphasized that it is not the class size that affects the learning process yet it is the teacher's quality and methodology that greatly counts (Maged, 1997; Nakabugo, 2003 and O'Sullivan, 2006).

Even though, teachers believe it is extremely important to decrease the number of students in classes, they confirm the significance of finding alternative teaching methodologies that are beneficial for elevating language learning in large classes. One way that is considered to be significant is to set good rapport between teachers and students and among students themselves which will help to minimize the anxiety where all in the class will feel as part in the same learning context. In spite of the different constraints large classes have on the teaching and 
learning outcomes, many teachers attempt to improve their level of teaching by employing multiple techniques such as team teaching, group work, reduce the workload and utilize whole class discussion. Chen (2005); Yazedjian et al. (2007) and Herington \& Weaven (2008) confirm that forming small group of students help to reduce the noise, save the time of performing a certain activity and allow teachers to concentrate on small numbers of groups instead on focusing on many individuals. It is also a useful technique to bring the distractions to its lowest limit by involving every student in the learning process. In words, engaging students in challenging activities where individuals or groups compete with one another would bring positive effects of large number in classes. Moreover, creating interesting activities that make students effectively occupied at the same time will increase students' on-task behavior, minimize students' boredom and bring loafing to its lowest level and that of course will promote the language learning. On a study conducted by Adrian (2010) on college students, he finds that active learning involves "students in doing things and thinking about the things they are doing" (p. 2).

Another beneficial remedy to overcome any problem tends to occur in large classes is to allow students to play an active role in class and involve them in all decision making about the classroom life as controlling the noise level or handling any disciplinary actions by setting rules and punishment among groups or individuals. Renaud, Tannenbaum \& Stantial (2007) believe that students are willing to abide by rules they set and not only that but they will make sure that these rules are effectively applied. In words, such action is expected to be useful in possible growth of some fruitful and compatible strategies in order to minimize the level of disturbance in class and maximize the level of learning.

Other scholars have also emphasized the importance of students' evaluation as a way of promoting the learning level (Blatchford et al., 2003; Al-Jarf, 2006 and Herington \& Weaven, 2008). Shepard (2000) reiterates this idea by stressing that assessing and evaluating students is a significant tool to the teaching and learning process, that:

To the right is an emergent, constructivist paradigm in which teachers' close assessment of students' understandings, feedback from peers, and student self- assessments would be a central part of the social processes that mediate the development of intellectual abilities, construction of knowledge, and formation of students' identities (p. 4).

\section{Methodology}

The main goal of this study is to explore the Saudi secondary teachers' perception towards teaching English in large classes and to determine the practical methodology to teach English in such context. Therefore, it is necessary to obtain the insider's view of the case by studying the participants' perceptions and the effect of class size on the teaching and learning process. In a case as such, a qualitative approach seems best convenient to classify these issues as it is interested on people as the tool of inquiry. It also consists of data that focuses on observation, interviews and surveys. In words, it is needed to provide deep understanding of the factors effecting teaching and learning in large classes.

For collecting the data, this exploratory qualitative research employs personal interviews of six Saudi secondary English teachers. The conducted interview is a semi structured one (see Appendixes A) where the "interviewer has a set of predetermined questions, but the interviewer is free to follow up a question with additional questions that probe further" (Perry, 2005: 119). Interviews let the researchers comprehend the phenomenon of learning desire through the interviewees' points of view not as the researchers might perceive it. In this interview, the researcher concentrated on class size and asked each participant to describe the size of her class using a four point scale as follow:1) very large, 2) large, 3) average, 4) small. Based on their answers, more open- end questions were asked regarding their perceptions of the appropriate number of students in each class and the reasons of their preference.

\subsection{Research Site}

This study was conducted in two public secondary schools in the city of Jeddah. Classes in government schools vary in terms of size as the average number of students is from 30 to 45 . Such number of students is found in schools in the south, west and east parts of the city where schools in the north side of Jeddah usually have fewer students. This variance is due to the number of private schools in the north where most of the upper class families live and those are the ones who could afford the expenses of private schools. All schools in Saudi Arabia, private or government are single sex, where female teachers teach only in girls' schools and male teachers teach boys only.

\subsection{Participants}

Most public secondary schools in Saudi Arabia have about four or five English teachers due to the large number of classes in this level. Two of these schools have been chosen to be the site of this research. Upon the researcher 
visit to both schools and after presenting the research plan to all English teachers, as the intention was to ask four volunteers from each school to join the research but only three teachers from each school were interested to take part. Before discussing my research in the introductory meeting, the researcher had to express her sincere gratitude to the volunteers who willingly joined even though they have a very busy schedule with not only teaching but also correcting note books and work books, cover the class of any absent teachers and take part, at least 2 periods weekly, in a school general activity.

Six Saudi $2^{\text {nd }}$ and $3^{\text {rd }}$ grade English teachers at two secondary schools in Jeddah had joined this study. All participants have taught classes which they consider large but have no experience of teaching smaller ones. All participants have long experience, 15 years and more, in teaching English to large classes. Such long experience seems to be a significant factor since the teachers' perceptions about large classes and the way they deal with them will be beneficial sources of data for this study. In the last ten years of their teaching, all participants have experienced teaching large classes ranging from 35 to 48 students per class with limited space and insufficient technical materials as tapes, tape recorder or data show. Yet, students' books, workbooks and teachers' book are always provided to all at the beginning of each academic year.

The aim of the study was explained to participants as to gain some understanding of their attitudes and beliefs towards teaching in large class which will help to expand the knowledge of this significant phenomenon. All participants were interviewed once where the questions concentrated on their experience in teaching large classes in secondary level, the challenges they encounter and the strategies they employ to overcome the problem. The transcripts were coded and analyzed according to teachers' responses to the research questions. Table 1 below displays interviewees' information.

Table 1. Demographic information of interviewees

\begin{tabular}{|c|c|c|c|c|c|}
\hline Participants & Education level & Age & $\begin{array}{c}\text { Years of teaching } \\
\text { experience }\end{array}$ & $\begin{array}{c}\text { No. of classes } \\
\text { per day }\end{array}$ & $\begin{array}{l}\text { Average No. of } \\
\text { students per class }\end{array}$ \\
\hline P. 1 & $\begin{array}{l}\text { BA/College of Arts \& } \\
\text { Humanities/English } \\
\text { Language Dept }\end{array}$ & 38 & 10 & 4 & $35-45$ \\
\hline P. 2 & $\begin{array}{l}\text { BA/College of Arts \& } \\
\text { Humanities/English } \\
\text { Language Dept }\end{array}$ & 40 & 13 & 5 & $30-48$ \\
\hline P. 3 & $\begin{array}{l}\text { BA/College of Arts \& } \\
\text { Humanities/English } \\
\text { Language Dept }\end{array}$ & 40 & 11 & 4 & $30-40$ \\
\hline P. 4 & $\begin{array}{l}\text { BA/College of Arts \& } \\
\text { Humanities/English } \\
\text { Language Dept }\end{array}$ & 43 & 18 & 4 & $35-50$ \\
\hline P. 5 & $\begin{array}{l}\text { MA/College of Arts \& } \\
\text { Humanities/English } \\
\text { Language Dept }\end{array}$ & 45 & 15 & 3 & $32-48$ \\
\hline P. 6 & $\begin{array}{l}\text { BA/College of Arts \& } \\
\text { Humanities/English } \\
\text { Language Dept }\end{array}$ & 45 & 10 & 5 & $35-45$ \\
\hline
\end{tabular}

\section{Data Analysis and Findings}

Analyzing the data is a step that a researcher makes to understand and interpret all of what have been said or seen. It is according to Merriam (2009) the process of making meaning. Through analyzing the interviews, the researcher could list a number of reasons that all participants believe to hinder the effectiveness of learning and teaching process and these are:

1) Mob manners of some students force teachers to focus on behaving students instead of using the time on more productive actions.

2) Classes with big number of students don't provide teachers with neither amble chances nor time to correct 
students either in their oral production or the written form.

3) Due to the number of classes teachers are teaching, 3 to 5 per day, which have big numbers of students up to 50, teachers have less opportunity to assess and evaluate their students' work and achievement, discuss their problems or provide any useful and constructive feedback.

4) Diversity among students confuses and puts too much pressure on their teachers leaving them mentally and physically exhausted.

5) Students in large classes receive less individual attention than their peers in small classes and that leads to dissatisfaction among students especially weak ones who will feel marginalized.

6) Students in large classes seem to be demotivated as they show no interest in either the lesson explained or activities presented by the teacher and that is due to the limited or lack of teachers' support.

7) Big number of students with limited space in class does not allow teachers to move around freely to monitor, observe and assess students during activities.

8) With the growth of class size, students have less chance to effectively participate and use the target language in class. As a consequence, loss of language interest will be class dominant.

Despite all the above mentioned problems which are believed to negatively impact the teaching and learning process, through their long experience in teaching and from the useful suggestions presented in workshops and seminars as well as discussion with peers, participants assume that concentrating on the teaching process and implementing various techniques lead to effective English teaching and learning. In the following section, some of the participants' remedial solutions are listed and elaborated.

\subsection{Challenges of Large Classes}

Even though all participants believe that teaching large classes is a huge burden as they end up feeling exhausted, they also find lots of opportunities and challenges while teaching big number of students. One of the participants (P.3) asserts that "teaching large classes provides me with many ways to improve my teaching". When asked about her preference for teaching small or large classes, participant (6) concedes that "even though I prefer to teach small classes, I find my current class (45 students) enjoyable, rewarding and challenging as we (me and my students) always dig for ways that help us to sail safely through the extreme situation". Similarly, participant (1) strongly admits that large classes provide her with many chances to develop her organizational talent and use all managerial proficiency she acquired during her teaching. By applying that, she manages to creatively organize the large classroom into a convenient welcoming learning setting. Agreeing to that, participant (5) confirms that "large classes are interesting and stimulating because they challenge me to try different methods and always come up with applicable solutions to make the class conducive to learning".

\subsection{Managing Large Classes}

One of the most problems related to large classes is classroom management. Therefore, it is certainly much of the art that large classes must involve assertiveness, leadership and active teacher who is able to control most of the class actions. To this, participants acknowledged that clear and strict rules must be declared at the beginning of the class and it is the teachers' role to effectively apply those rules when needed and may become a bit lenient when actions turn out to be under control. Discussing questions that are related to classroom management, participant (4) professes that "when meeting students for the first time, setting classroom' rules is one of my priorities. She carries on "I find it very useful to discuss all my rules, write them in Arabic and English and then pass them around for all students to read and sign. Not only have that, I even encouraged my students to set forth a punishment for those who may not abide by the class rules. She also raises another point by saying "I don't mind teaching large number of students where there is adequate space for me to move around and be able to reach the students at the back to control any noise or distraction". On the other hand, as a respond to the question about the number that makes a class large or small, participant (3) says "for me a class of 35 students is considered to be good where as a class of 25 is ideal but 36 and more is really a big class".

\subsection{Students-Centered rather than Teacher-Students Approach}

Generally speaking, teaching all subjects in Saudi Arabia, where English is no exception, involves the traditional passive view of teaching where teachers are spoon feeding the information to students and presenting the materials to them through a lesson-based format. Recently, many seminars and workshops for all subjects are held to concentrate on a more modern view of leaning to shift from the old method of delivering information to students to more active and engaged students. From the finding of their study, De Capraiis, Barman \& Magee (2001) suggest that lesson directs students to remember facts while group discussion produces positive outcomes 
and leads to higher level of thinking, recognition and elaborating. Participants, in this study, strongly affirmed that encouraging students to be active members in class by dominating class discussion leads to efficacious language learning. They also emphasize the importance of collaborative tasks as group work, pair work and peer editing. As a respond to Q. 1 about her teaching method, participant 4, points out that "in large classes, I always try different methods that facilitate the learning process". She explains "if method X is not good enough, I switch to another one. Saying more "I started using the teacher-centered approach then realized it is not working effectively so I turned to more effective method which is students-centered and only then I found that my students are becoming more responsible and much involved in the learning process which make them better recipients rather than passive learners".

Interestingly enough, through her long experience of teaching, participant (5) finds it difficult to assess all individuals in the class and that encourages her to search for a leading method which offers the best for all in her class. Thus, implementing group work helps her to generate more interactive settings and embrace affective teaching environment which elevate her students' autonomy and arise their responsibility towards learning. On the other hand, participant (2) concludes that peer editing encourages her students to take part in different writing tasks starting with easy task to high level of editing and that boosts students' awareness of the writing task and elevates their self-confident through correcting others' work.

\subsection{Small Group not the Whole Class}

Regarding the big number of students in class, all participants strongly express the difficulty to monitor, observe or correct individuals. Therefore, in certain tasks, participant (1) tends to apply the technique of dividing her class into small group which makes it easier and less hectic to monitor 8 groups instead of going around 45 students. She mentions that "one of the biggest problems I encounter in my large class is observing the class while performing activities. Therefore, dividing my students into small groups facilitates my job and saves my time". Participant (6), who managed to find remedial solutions, declares "games, role plays and interviews are my favorite methods. By dividing the class into small group and involving each member in a certain task which is relevant to her needs, I manage to create a highly competitive setting with less or almost no disturbance. In this regard, Cooper and Robinson (2000) found that small-group work can "contribute to effective teaching and learning by promoting cognitive elaboration, enhancing critical thinking, providing feedback, promoting social and emotional development, appreciating diversity and reducing student attrition" (p. 181).

From all that mentioned above, we can say that it is possible for English to be taught and improved in large classes in Saudi secondary schools by producing an interactive model of teaching/learning process where there is a great interaction between teachers and students and among classmates in the shape of pair and group work. It is also recommended that even though large classes are daunting and lead to huge burden, English teachers should not be distracted by any chaotic situation and carefully plan to control the class as well as to create challenging activities, employ appropriate materials and valid methodology which may result on great impact on English teaching. It should emphasized that teachers have to be flexible and adventurous by using various teaching strategies, detecting problems created by large classes, identifying their students' needs and then gear teaching to overcome the problem.

\section{Limitations of the Study}

The general purpose of the present study is to determine what problems are presented in teaching and learning English in large classes and to find remedial solutions to elevate the teaching/learning process. However, it must be admitted that this study is a personal effort that may have shortcomings that can be tackled in other studies. From those, first, the small number of participants in this study (6 teachers) constitutes a clear limitation as the represented data generated from their interviews may not be enough to generalize the result to other contexts either inside or outside Saudi Arabia. Further, the data is collected from English teachers teaching large classes in secondary schools in Saudi Arabia where the strategies proposed by the review may not be suitable for the above mentioned context as it has been proven that teaching success or failure is affected by context. Moreover, as mentioned earlier, the methodology used for data collection is interviews only with no classes' observation while including observational method would allow the researcher to actually see a real practice in large classes and that would enrich the data. In a word, the problem of teaching and learning English in large classes is a large domain with many aspects that can not be tackled in one study. Yet, it seems fair to say that the result of this study is a path to others that leads to understand this dilemma where ample chances are provided for further investigation to find remedial solution and that will bring a new dynamism to the body of literature about teaching English in large classes in the developing countries. It will also offer teachers with deep understanding 
about the realities of large classes and encourage them to share ideas and exchange experiences with others in similar contexts.

\section{Conclusion}

Synthesizing the earlier views, we can say that large classes are not firmly a pedagogical dilemma as the complications found in large classes raise more demands and actions from language teachers in large classes compared with their counterparts teaching smaller ones. Taken together, the literature review and the study findings we can say that class size has a significant role in the teaching and learning process. Therefore, it is important to explore various methods and apply effective strategies that minimize the effects of large classes and elevate the teaching and learning level to its highest standard. Hence, the effectiveness of any techniques may vary from one context to another as it relies heavily on different aspects such as students, teachers and facilities available in a certain school.

\section{References}

Adrian, L. M. (2010). Active learning in large classes: Can small interventions produce greater results than are statistically predictable? Active learning in large classes. The Journal of General Education, 59(4), 223-237.

Al-Jarf, R. (2006). Large student enrollments in EFL programs: Challenges and consequences. Asian EFL Journal Quarterly, 8(4), 8-34.

Blatchford, P. (2003). A systematic observational study of teachers' and pupils' behavior in large and small classes. Learning and Instruction, 13, 569-595.

Blatchford, P., \& Mortimore, P. (1994). The issue of class size for young children in schools: What can we learn from research? Oxford Review of Education, 24, 411-428.

Blatchford, P., Moriarty, V., Edmonds, S., \& Martin, C. (2002). Relationships between class size and teaching: A multimethod analysis of English infant school. American Educational Research Journal, 39(1), 101-132.

Brown, H. D. (2001). Teaching by principles. White Plains: Addison Wesley Longman, Inc.

Chen, P. (2005). Effectively implementing a collaborative task-based syllabus (CTBA) in EFL large-size Business classes. English for Specific Purpose World, 1-14.

Cooper J. L., \& Robinson, P. (2000). The argument for making large classes seem small. New Directions for Teaching and Learning, 81, 5-16.

De Caprariis, P., Barman, C., \& Magee, P. (2001). Monitoring the benefits of active learning exercises in introductory survey courses in science: An attempt to improve the education of prospective public school teachers. The Journal of Scholarship of Teaching and Learning, 1(2), 1-11.

Finn, J. D., Pannozzo, G. M., \& Achilles, C. M. (2003). The "why's" of class size: Student behavior in small classes. Review of Educational Research, 73(3), 321-368.

Harmer, J. (2000). How to Teach English. Foreign Language Teaching and Research Press.

Hattie, J. (2005). The paradox of reducing class size and improving learning outcomes. International Journal of Educational Research, 43, 387-425.

Hayes, U. (1997). Helping teachers to cope with large classes. ELT Journal, 1, 31-38.

Heppner, F. (2007). Teaching the large college class. San Francisco: Jossey-Bass.

Herington, C., \& Weaven, S. (2008). Action research and reflection on students approaches to learning in large first year university classes. The Australian Educational Researcher, 35(3), 111-134.

Hess, N. (2001). Teaching Large Multilevel Classes. Cambridge: CUP.

Kennedy, C., \& Kennedy, J. (1996). Teacher Attitudes and Change Implementation. System, 24(3), 351-360. Elsevier Science Ltd.

Kumaravadivelu, B. (2006). Understanding language teaching: From method to postmethod. (Routledge ed.). Mahwah, NJ: Lawrence Erlbaum.

Lazear, E. P. (2003). Educational production. The Quarterly Journal of Economics, 116(3), 777-803.

Locastro, V. (1989). Large Size Classes: The Situation in Japan. Lancaster-Leeds Research Project.

Locastro, V. (2001). Teaching English to large classes. TESOL Quarterly, 35(3), 493-506. 
Maged, S. (1997). The pedagogy of large classes: Challenging the "large class equals gutter education" myth. M.Phil dissertation. University of Cape Town, South Africa.

Merriam, S. B. (2009). Qualitative research: A guide to design and implementation. San Francisco, CA: Jossey-Bass.

Miller-Whitehead, M. (2003). Compilation of class size findings: Grade level, school and district. Paper presented at the Annual Meeting of the Mid-south Educational Research Association.

Mulryan-Kyne, C. (2010). Teaching large classes at college and university level: Challenges and opportunities. Teaching in Higher Education, 15(2), 175-185.

Nakabugo, M. G. (2003). Closing the gap? Continuous assessment in primary education in Uganda. Thesis presented for the Degree of Doctor of Philosophy, Graduate School in Humanities, University of Cape Town.

Normore, A., \& Ilon, L. (2006). Cost-effective school inputs: Is class size reduction the best educational expenditure for Florida? Educational Policy, 20, 429-454.

O'Sullivan, M. C. (2006). Teaching large classes: The international evidence and a discussion of some good practices in Ugandan primary schools. International Journal of Educational Development, 26, 24-37.

Pedder, D. (2006). Are small classes better? Understanding relationships between class size, classroom processes and pupils' learning. Oxford Review of Education, 32(2), 213-234.

Perry, J. F. (2005). Research in applied linguistics. New York, NY: Routledge.

Pong, S., \& Pallas, A. (2001). Class size \& 8th grade math achievement in the U.S. and abroad. Educational Evaluation and Policy Analysis, 23(3), 251-273.

Renaud, S., Tannenbaum, E., \& Stantial, P. (2007). Student-centered teaching in large classes with limited resources. English Teaching Forum, 45(3), 12-17.

Resnick, L. (Ed.) (2003). Class size: Counting kids can count. American Educational Research Association, 1(2), $1-4$.

Shamim, F., Negash, N., Chuku, C., \& Demewoz, N. (2007). Maximizing learning in large classes: Issues and options. Addis Ababa, Ethiopia: British Council.

Shepard, L. A. (2000). The role of assessment in a learning culture. Educational Researcher, 29(7), 4-14.

$\mathrm{Su}, \mathrm{T}$. (2005). Approaches of increasing teaching efficiency in large English classes. Teacher's Journal, 1, 33-34.

Tan L. (2009). Large class English teaching in junior high schools in rural area and cooperative learning. English Teaching, 7, 180.

Ur, P. (1996). A Course in Language Teaching. Cambridge: Cambridge University Press.

Yazedjian, A., \& Kolkhorst, B. (2007). Implementing small-group activities in large lecture classes. College Teaching, 55(4), 164-169.

Yu, J. (2004). Problems and strategies of teaching English in large college classes. Journal of Chongqing University of Post and Telecommunication (Social Science), 3(1), 139-140.

Zhang, J. (2002). The survey and analysis of big class English teaching. Journal of North China Institute of Water Conservancy and Hydroelectric Power (Social Sciences Edition), 18(4), 92-94.

Zhang, M. (2008). Challenges and solutions of teaching large classes. Education Science and Culture Magazine, 29, 68-69.

Zhang, L. (2010). Problems of teaching English in primary large classes in rural areas and application of group study. Journal of Guangxi Normal University for Nationalities, 27(1), 129-131.

\section{Appendix}

Teachers' Interview

1. Personal details:

1) Name

2) Qualifications

3) Teaching experience 
4) School

5) Grade

6) No. of classes per term

7) No. of students in each class

2. Teaching methodology

1) What kind of teaching method you employ in class?

2) As a teacher list some of your strengths points and weaknesses (if any).

3) Do you perceive your class as very large, large, average or small? Justify!

4) What is the students' number that makes the class large?

5) Do you prefer teaching large/small classes? Why?

6) What are the advantages of large/small classes?

7) In your opinion what are the disadvantages of large/small classes?

8) In your opinion what is the most difficult task for your students to perform in Large classes?

9) In your opinion how do large classes constrain teachers, affect students and hinder the learning process?

10) What are your best methods to control any misbehaved actions?

11) What are the roles your students have in large classes?

12) In your opinion what is the ideal students' number that facilitates the learning process?

13) Throughout your years of teaching, what factors have influenced you the most?

14) What instructional techniques do you use to maximize the level of outcome in large class?

15) Do you use any sort of technology? If yes, how? If no, why?

16) Do you feel stratified about what you have offered to your students? If yes, why? If no, why?

\section{Copyrights}

Copyright for this article is retained by the author(s), with first publication rights granted to the journal.

This is an open-access article distributed under the terms and conditions of the Creative Commons Attribution license (http://creativecommons.org/licenses/by/3.0/). 